\title{
PROJECTED RETIREMENT WEALTH AND \\ SAVINGS ADEQUACY IN THE HEALTH AND RETIREMENT STUDY
}

\author{
James F. Moore \\ Olivia S. Mitchell
}

Working Paper 6240 


\title{
PROJECTED RETIREMENT WEALTH AND SAVINGS ADEQUACY IN THE HEALTH AND RETIREMENT STUDY
}

James F. Moore

Olivia S. Mitchell

Working Paper 6240

http://www.nber.org/papers/w6240

\author{
NATIONAL BUREAU OF ECONOMIC RESEARCH \\ 1050 Massachusetts Avenue \\ Cambridge, MA 02138 \\ October 1997
}

Research support for this study was provided by the Wharton School, the Penn Aging Research Center, and the Boettner Center of Financial Gerontology. The authors remain solely responsible for opinions contained herein. This paper is part of NBER's research program in Aging. Any opinions expressed are those of the authors and not those of the National Bureau of Economic Research.

(C) 1997 by James F. Moore and Olivia S. Mitchell. All rights reserved. Short sections of text, not to exceed two paragraphs, may be quoted without explicit permission provided that full credit, including $\mathbb{C}$ notice, is given to the source. 
Projected Retirement Wealth and Savings

Adequacy in the Health and Retirement Study

James F. Moore and Olivia S. Mitchell

NBER Working Paper No. 6240

October 1997

JEL Nos. J14, G23, H55

Aging

\section{ABSTRACT}

Low saving rates raise questions about Americans' ability to maintain consumption levels in old age. Using the Health and Retirement Study, this paper explores asset holdings among a nationally representative sample of people on the verge of retirement. Making reasonable projections about asset growth, we assess how much more people would need to save in order to preserve consumption levels after retirement. We find that the median older household has current wealth of approximately $\$ 325,000$ including pensions, social security, housing, and other financial wealth, an amount projected to grow to about $\$ 380,000$ by retirement at age 62 . Nevertheless, our model suggests that this median household will still need to save $16 \%$ of annual earnings to preserve pre-retirement consumption. For retirement at age 65 , assets are expected to be about $\$ 420,000$ and required additional saving totals $7 \%$ of earnings per year. These summary statistics conceal extraordinary heterogeneity in both assets and saving needs in the older population. Older high wealth households have 45 times more assets than the poorest decile and this disparity increases with age. There are also large differences in prescribed saving targets, ranging from $38 \%$ of annual earnings for those in the lowest wealth decile to negative rates for the wealthiest decile.

James F. Moore

Department of Insurance and Risk Management

The Wharton School

3641 Locust Walk, 304 CPC

Philadelphia, PA 19 104-62 18

moore86@wharton.upenn.edu
Olivia S. Mitchell

Department of Insurance

and Risk Management

The Wharton School

3641 Locust Walk, 304 CPC

Philadelphia, PA 19 104-62 18

and NBER

mitchelo@wharton.upenn.edu 


\title{
Projected Retirement Wealth and Savings Adequacy in the Health and Retirement Study
}

\author{
James F. Moore and Olivia S. Mitchell
}

Future retirees will bear a larger responsibility for ensuring their own wellbeing in retirement, judging from projected social security system insolvency and the national shift from defined benefit to defined contribution private pension plans. Yet household saving rates in the United States have dropped from over $10 \%$ in the 1950's to around $3 \%$ in the first half of the 1990's (Gokhale et al. 1996). This discouraging pattern raises serious concerns about Americans' ability to maintain consumption levels in old age. They are underscored by a recent research controversy over whether workers are adequately prepared for retirement. A comparison of baby boomers' assets to those of their parents recently argued that saving for retirement is on track (CBO 1993). But using a different benchmark, a recent study concluded that US households were saving at only one-third the rate needed to fund a comfortable retirement (Bernheim 1992, 1994). The present paper contributes to this debate by using a rich new dataset, the Health and Retirement Study, to explore patterns of asset accumulation and saving shortfall among a cohort of older Americans. Our goals are to determine (1) how much retirement wealth older people on the verge of retirement actually have, and (2) how much more they would need to save if they wished to preserve consumption levels after retirement. Our research will show that the median older household is projected to 
have retirement wealth of approximately $\$ 400,000$, yet will still need to save $16 \%$ of annual income to preserve pre-retirement consumption. This summary statistic conceals extraordinary heterogeneity in both assets and saving needs in the older population.

In what follows we first discuss the rationale for the replacement rate model and prior studies examining saving behavior. Next we describe wealth levels and composition for HRS households in 1992, and show how those wealth patterns would be expected to change at retirement ages of 62 and 65 . These wealth measures are then converted to saving rates, which are then compared to optimal saving rates required to smooth lifetime consumption. A final section spells out implications.

\section{Saving Patterns and Replacement Rates in a Life Cycle Model}

Economic models of saving behavior rely on a life cycle model in which individuals are posited to maximize utility by smoothing consumption through time. In this framework, people are predicted to save when they have periods of relatively high income, and dip into accumulated savings or borrow when income is relatively low, including in retirement. ${ }^{2}$ One recent study implementing an augmented life cycle model derived optimal saving rate paths using dynamic programming, in which the optimal saving path proves to increase in age up to

\footnotetext{
${ }^{1}$ Franco Modigliani was a believer in this model that garnered him the Nobel prize. When asked what he would do with his prize money, he is alleged to have responded that he would spend $1 / \mathrm{T}$ of it where $\mathrm{T}$ represented the remaining (and assumed known) years of life remaining.
} 
retirement (Bernheim 1992). ${ }^{2}$ Predicted saving rates are then compared with actual rates derived in empirical analysis of respondents. Bernheim concluded that workers in his sample saved at only one-third (35\%) the prescribed rate that they should have been saving, if they sought to meet target consumption goals. However this estimated shortfall omitted from peoples' wealth levels the value of their net housing wealth, on the argument that relatively few people liquidate their housing on retirement. ${ }^{3}$ His calculations of saving shortfalls if housing assets are included in retirement wealth is somewhat lower - on the order of about $16 \%$ per year. The extent to which Bernheim's results are generalizable is unclear, however, because his sample is relatively small and better off than the average population. In addition he focuses on the typical saving pattern rather than examining the dispersion in saving shortfall, a topic of central interest below.

A different approach to the retirement saving question relies on a "replacement rate" approach. As we describe below, this methodology evaluates the ratio of household income needed to finance desired retirement consumption relative to annual pre-retirement income. The object here is to equate pre-

\footnotetext{
2 Bernheim solves backward from the household's last possible period, T, in which all wealth and income is assumed to be exhausted. Then the household is posited to maximize utility in period T- 1 given uncertainty of living to period T. Actual consumption (and hence saving) is determined by solving for $\mathrm{C}_{\mathrm{T} \cdot 1}$ given $\mathrm{U}\left(\mathrm{C}_{\mathrm{T}}\right)$, the utility of consumption; $\beta$, the rate of pure time preference (discount); pT.1, the probability of surviving from time T-1 to time $\mathrm{T}$; and the objective function $\max U\left(\mathrm{C}_{\mathrm{T}-1)}\right)+\mathrm{pT}$. ${ }_{1} \beta U\left(C^{*} T\right)$. The process is then resolved for periods back to the starting point, and under a range of assumptions regarding other variables.

3 Whether housing wealth should be included in a tally of retirement assets is a hotly debated issue. Retirees are often reluctant to move from the houses they lived in while working, in which case they see their housing wealth as an emergency contingency fund (and possibly serves as a bequest). In addition, moving costs can make accessing housing equity expensive. However we note that housing wealth may be used to increase consumption through mechanisms such as second
} 
retirement and post-retirement consumption on an expected value basis. ${ }^{4}$ Recent work by Palmer (1988, 1991, 1993) uses several cross-section Consumer Expenditure Surveys to examine this issue, and concludes that gross replacement rates have varied over time depending on tax changes and household saving rates. An invaluable dataset with which to explore older Americans' wealth positions as they near retirement is the Health and Retirement Study (HRS). This extensive questionnaire on wealth and income was addressed to a nationally representative sample of 7607 households in 1992, where at least one respondent was age 51 to 61 and their spouses. ${ }^{5}$ Under certain restricted conditions, researchers may also access special files needed for measuring pension and social security wealth (described in more detail below). One previous study using these data by Mitchell, Olson, and Steinmeier (hereafter MOS 1996), explored expected present values of social security benefits for HRS respondents. A second analysis, by Gustman, Mitchell, Samwick, and Steinmeier (hereafter GMSS 1997) examined both pension and social security wealth for these same households, using actual pension information and imputed or estimated social security data.

mortgages, home equity loans, and reverse mortgages, so in this paper we include housing wealth in the set of assets that could finance retirement.

${ }^{4}$ From a theoretical economic perspective, this is less appealing than a true life cycle-dynamic programming approach as it ignores utility theory and behavioral responses to uncertainty. However, it is a popular model among retirement planning practitioners and can be seen as a relatively tractable approximation or rule of thumb to the life cycle model.

${ }^{5}$ The HRS is structured as a longitudinal or panel data set with households re-sampled every two years, and should prove a fertile source for researchers in the future. Currently only the first wave is available in public release, and only public release data can be merged with the pension and social security data to be described below. Further information on the HRS is available by Internet

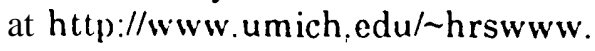


These two studies show that estimated median total household wealth for HRS respondents on the verge of retirement totaled approsimately $\$ 340,000$ in 1992 (mean values were approximately half a million dollars). Total wealth depends on four components: net financial wealth, net housing equity, and the present value of expected pension and social security benefits. At face value, these wealth amounts would seem to indicate that the "average" HRS household is in relatively good shape for retirement. But in a follow-up study, Mitchell and Moore (hereafter MM, 1997) assess the adequacy of these asset accumulations, and suggest that the median older American family faces a substantial saving shortfall. Specifically, MIM project anticipated wealth as of age 65 for a hypothetical median couple, and then compare this with the level of wealth needed to sustain the family's pre-retirement consumption derived from targets offered by Palmer (1994). The required saving rate needed to build assets to desired levels for this representative HRS household is quite high - between $13 \% \cdot \mathbf{2 3} \%$ of gross income per year in the decade leading up to retirement. In the next section we will explore whether this conclusion - derived for a representative couple - is informative for the older population as a whole.

\section{Initial and Projected Wealth in the Health and Retirement Study}

The present study improves on previous analyses in three ways. First, we evaluate retirement wealth and saving needs for the entire nationally representative sample of HRS households. This is important since focusing on a median family conceals wide differences across the population, and asset levels are 
quite disperse across older households. Second, our approach determines replacement and saving rates jointly given the households earnings level and projected assets to age 62 and 65 . Third, we assess saving needs in the older population as a whole, and describe these patterns by income and wealth level.

The starting point for our analysis is an examination of HRS households' net wealth levels. The primary components of this wealth can be broadly categorized into four groups?

1) net financial wealth, including saving, investments, business assets, and non-residential real estate less outstanding debt not related to housing;

2) net housing wealth, or the current market value of residential housing less outstanding mortgage debt;

3) pension wealth, or the present value of employer-sponsored retirement benefits; and

4) the present value of social security benefits.

"Current" values for net financial wealth and net housing wealth are those reported by-respondents in the HRS 1992 survey. Values for pension and social security wealth reflect actuarial present values of these contingent income sources based on service and salary through 1992 (see the Appendix). Pension wealth for respondents with employer-provided pensions is calculated using software developed at the Institute for Social Research at the University of Michigan This software uses information collected from employers of HRS participants to calculate

'All wealth values reported in this paper are weighted by HRS sample weights. 
benefit streams based on workers' salary and service. Social security wealth is calculated using administrative records on covered earnings and benefit formulas available from the Social Security Administration as described in Mitchell, Olson and Steinmeier (1996).

Values of current wealth by deciles are reported in Table 1. One result that will not be surprising to many is the wide disparity of wealth across the population, even though it is on the verge of retirement. The mean value in the tenth, or wealthiest decile, is $\$ 1.8$ million, or 45 times that of the mean value for the poorest decile. The composition of this wealth also differs dramatically across wealth deciles. For the poorest decile, the value of anticipated social security benefits is greater than total wealth (107\%), as a result of negative net housing wealth. At the other end of the wealth distribution, expected social security benefits comprise less than one-tenth of household wealth.

Graphical representations of the data are also useful. Dollar estimates of total wealth appear in Figure 1, and wealth sources by percentage are given in Figure 2. Mẹean values for almost all sources monotonically increase in total wealth, but the relative importance of the individual components varies across group. For example, to focus first on social security payments, the present value of these benefits falls as a fraction of total wealth as wealth levels rise, because of the plan's redistributive benefit formulas. Net housing wealth is negative for the lowest decile, indicating that these households have over-levered their housing stock. Beyond the poorest group, housing assets rise as a fraction of wealth, attaining almost one-fifth of wealth for households in the middle of the total wealth 
distribution, and then fall in relative importance for the wealthiest households. Net financial wealth is rare among the poorer half of the wealth distribution: households in the bottom two-fifths have less than $\$ 50,000$ in assets of this sort. Only the top two-fifths of the population have more than $\$ 100,000$ in net financial assets.

Looking across the entire HRS sample, we see that the median household group holds slightly over $\$ 325,000$ in total wealth, while the mean household has almost $\$ 480,000$. Not only do levels differ; composition also varies across the mean and median household. At the median, the split can be characterized as a "rule of fifths." Social security constitutes two-fifths of total wealth, and the other three asset categories each comprise a fifth. This balance is shifted for the mean, since net financial wealth plays a much more prominent role for wealthier households (it comprises as much as two-thirds of wealth for the wealthiest group represented).

It is interesting to compare our results to those reported by GMSS (1997), who obtained a mean value of almost $\$ 500,000$ in total net wealth, and $\$ 340,000$ for the median $10 \%$ of households.7 These are very close to our estimated values of $\$ 478,000$ and $\$ 325,000$, respectively. Our figures differ because, first, GMSS calculate a value for retirement health insurance ( $\$ 7600$ at the mean) which we do not include; and second, our analysis uses social security wealth using actual administrative earnings records. By contrast, GMSS did not use the restricted

7 The value for the median $10 \%$ is the mean value for those households falling between the 45 th and 55 th percentile of the wealth distribution. This value is presented instead of the true median to allow for representative disaggregation. 
administrative records data, but instead estimate it from self reported earnings data. Their estimated figures of $\$ 134,000$ and $\$ 145,000$ for the mean and median values are slightly higher - around $10 \%$-- than our mean and median of $\$ 120,000$ and $\$ 134,000$ calculated using actual Social Security Administration records. ${ }^{8}$ Our estimates for pension wealth are very close to theirs, differing by less than $10 \%$ $(\$ 1,000)$ at the mean, $(\$ 117,000$ versus $\$ 116,000)$.

Having established current wealth levels and distributions for the HRS, the nest step is to project existing assets to an assumed retirement age. We do this because two households holding the same initial wealth in different forms could prove to be in quite different circumstances a decade later, even assuming no additional saving out of earnings. To examine this possibility we project assets to two assumed retirement dates, the early and normal retirement ages for social security. Age 62 is the age of earliest entitlement for early social security retirement benefits and also corresponds to the modal retirement age in the United States. The social security normal retirement age, historically 65 , is the age at which an individual is eligible for full, unreduced Social Security benefits and is a traditional benchmark age. 9

While it is easy to specify an assumed retirement age for an individual, it is more problematic for a married couple. Spouses do not necessarily retire at the same time and even when they do, it is not clear which partner's age keys the

\footnotetext{
${ }^{3}$ GMSS recognize the upward bias of their numbers but were not permitted at that time (February 1997) to combine pension with social security administrative data.
} 
decision. In the present study we follow HRS practice where the survey interviewer designated as the primary respondent the household member with the greatest knowledge of the household's financial matters. Usually this respondent was ageeligible for the HRS survey; in this case we assume the retirement assumption is triggered on this person's attainment of age 62 or 65 . If the primary respondent was not HRS age eligible, this guarantees that the secondary respondent is age eligible. In this instance, we assume that the retirement age is keyed off the attainment of 62 or 65 by this household member.

Asset values for each of these classes are projected to these retirement dates using a range of projection technologies and assumptions.10 Net financial wealth is projected forward using averages of market returns based on historical rates. Historical return rates are drawn from Ibbotson (1996). Housing wealth is projected forward using survey data on the purchase price of the respondent's house, year of purchase, outstanding debt owed on homes, and mortgage payment amount and frequency. The process consists of increasing the market value of the house into the future, and also reducing the debt outstanding on the house. We assume that the market value of the house grows in line with the general inflation rate so there is no real appreciation in housing values; rather what does change is the amount owed on the house for those with outstanding mortgage values. Each mortgage payment decreases the remaining principal on the mortgage. Respondents' pension

\footnotetext{
9 Legislation is increasing the normal retirement age to 67 over a period of several years, and for a few HRS respondents the normal retirement age will be age 66 .

10 More discussion of projection methodology and rates of growth are given in the Appendix.
} 
and social security wealth values are projected assuming workers remain employed to their respective retirement ages. Pension benefits are derived based on the plan provisions of employer provided pensions and respondents' answers to salary and years of service (where appropriate). Social security projected amounts are computed as described in MOS (1996). Present values of benefits are calculated using mortality, interest rate, inflation, and wage growth assumptions as described in the Appendix; all values are in 1992 dollars.

Initial and projected wealth values for HRS respondents are reported in Table 2. Median household wealth is anticipated to grow by almost $20 \%$ in real terms by age 62 , to slightly over $\$ 383,000$. If retirement were postponed until 65 , the median household wealth value rises by approximately $30 \%$, or $\$ 421,000$. Mean increases are similar in percentage terms and translate to wealth figures of approximately $\$ 566,000$ and $\$ 625,000$ at ages 62 and 65 respectively.

While percentage changes are similar by decile, those in the top two wealth deciles are projected to have amassed considerable additional net worth. The second wealthiest decile has more than $\$ 1$ million dollars on average, and the wealthiest has more than $\$ 2.3$ million. For the wealthiest decile, this is largely due to financial and business assets which make up some $60 \%$ of assets ( $\$ 1.4$ million). Pension assets make up 23\% ( $\$ 535,000$ on average), leaving social security and, surprisingly, net housing wealth as relatively unimportant $8 \%$ each. Yet this is still almost $\$ 200,000$ for both. Pension wealth plays a larger role for the ninth decile comprising some $38 \%$ of total wealth 
The most dramatic change in projected benefits is attributable to increases in pension wealth, which is found to rise by one-third by age 62 , and by one-half by age 65 for the mean household. For the median respondent family, pension present value figures rise by nearly one-half and three-quarters for the same ages. By contrast, social security wealth increases only $7-8 \%$ by age 62 , and by about $20 \%$ by age 65. Much of this difference is attributable to the well-known nonlinear accrual pattern common to employer pensions, rewarding additional service at older ages. A smoother pattern characterizes social security benefits, since most HRS households have already reached entitlement and additional service changes their benefits by relatively little. ${ }^{11}$ About the mean and median, the different rate of growth of these asset classes has relative little impact in changing the composition of projected wealth. Pension wealth does play a slightly larger role at the assumed retirement ages, mostly gaining a few percentage points from net housing wealth and social security.

As social security plays a much greater role for the poorest decile, their wealth gains to age 62 and 65 are relatively modest. The value of their social security wealth rises by about $\$ 6,000$ to age 65 , matched by gains in housing wealth. Unfortunately, about half of these gains are offset by declines in the average value of their financial and other assets, mainly due to decreases in vehicle

\footnotetext{
11 In other words the payroll tax at older ages is more of a true tax than at younger ages where additional benefits may be accrued by extra years of contribution to social security.
} 
value. ${ }^{12}$ At 65 this poorest decile still has total wealth of under $\$ 50,000$, the vast majority of which (98\%) is comprised of future social security benefits.

It is important to note that averaging may mask significant differences at the household level. For example, a household with $\$ 100,000$ in pension wealth and no housing assets at 55 looks very different at 62 , than would an equivalent household with a $\$ 100,000$ house that is completely paid for. Both households will look different than a household with the same $\$ 100,000$ in net housing wealth but with a substantial mortgage outstanding. Nonetheless, as we shall show below, prospects are slim for projected movement across wealth deciles with age. Most of those households that are projected to change deciles either move up or down a only single decile. In other words, initial wealth is the best predictor of projected retirement wealth: our estimated correlation between initial and projected wealth to age 62 is $0.9^{\prime} 7$. There is a much weaker correlation between initial earnings and initial wealth, of 0.44 , and a nearly identical correlation between earnings and projected wealth.

\section{Saving Needs, Replacement Rates, Wealth, and Income}

Having established that asset holdings are quite disperse in the HRS, the question remains as to what this implies about saving needs and replacement rates for retirement. In this section we assess target replacement and saving rates

1:2 We assume vehicles depreciate over a lo-year period. 
jointly, given initial earnings levels and the households' projected assets at age 62 and 65 .

To solve for saving and replacement rate targets simultaneously, we begin with the basic replacement rate concept. This equates net income pre-retirement to net income post-retirement: ${ }^{13}$

$$
Y_{P}-T_{P}-S=Y_{F}-T_{F}
$$

where $\mathrm{Y}_{\mathrm{P}}$ is pre-retirement income, $\mathrm{T}_{\mathrm{P}}$ is pre-retirement taxes, $\mathrm{S}$ is saving, $\mathrm{Y}_{\mathrm{F}}$ is post-retirement income, and $\mathrm{T}_{\mathrm{F}}$ is pre-retirement taxes. Rearranging (1), dividing through by $Y_{P}$, and expressing saving as a percent of income, $S=s Y_{P}$, gives the formula for replacement rate, $R R$.

$$
R R=\frac{Y_{P}(1-\mathrm{s})-T_{P}+T_{F}}{Y_{P}}=\frac{Y,}{Y_{P}}
$$

The replacement rate gives a target income level such that a household may smooth consumption before and after retirement.

The future income stream, $\mathrm{Y}_{\mathrm{F}}$, may then be converted to a level of wealth needed to sustain that income level in retirement by multiplying by an appropriate annuity factor, AF. ${ }^{14}$ Thus the wealth level required to maintain a smooth consumption profile in retirement is:

${ }^{13}$ One could estend the analysis by allowing for changes in specific consumption prior to and after retirement and Palmer (1994) does this. In this paper we do not model this possibility and note that consumption choices are a decision variable rather than an exogenous variable, dependent on assets and income.

14 Annuity factors are calculated with the same assumptions used for valuing pension and social security wealth, a real interest rate of $2.3 \%$, and the moderate assumptions used in the long range projections of the Social Security Administration. Annuity factors employ the SSA mortality tables 


$$
A F^{*} Y_{F}=A F^{*} R R^{*} Y_{P}=A F\left[Y_{P}(1-s)-T_{P}+T_{F}\right]
$$

The difference between this need level and the projected value of assets already held by any given household, PROJ, is the amount that must be saved between now and retirement, or the shortfall in projected retirement assets. This wealth shortfall may be defined as:

$$
A F^{*} Y_{F}-P R O J=A F\left[Y_{p}(1-s)-T_{p}+T_{F}\right]-P R O J
$$

The wealth shortfall may finally be used to determine a prescribed saving rate. This rate represents what the households would need to save as a percent of income each year until retirement to achieve the projected consumption standard. Assuming that a wealth shortfall is met by saving some level percent of earnings per year, the amount saved at retirement would be:

$$
\sum_{t=1}^{T} Y_{C}(1+w g)^{t}(1+r t n)^{T-t} s=s Y_{C} \sum_{t=1}^{T}(1+w g)^{t}(1+r t n)^{T-t}=s Y_{C} Z
$$

where $Y_{C}$ is the household's current income, and wg and rtn are assumed rates of wage growth and return on savings, respectively. Using (4) and (5) we can then solve for a rate of saving s. Equating the two equations and solving for s gives

$$
s=\frac{A F\left[Y_{C}(1+w g)^{T}-T_{P}+T_{F}\right]-P R O J}{Y_{C}\left[Z+A F(1+w g)^{T}\right]}
$$

We note that it is not appropriate to simply pick a desired replacement rate and solve for the resulting saving rate, or vice-versa. This is because a given replacement rate might imply an infeasible saving rate given a household's earnings and projected assets. In addition, taxes depend on how much the 
household has saved. ${ }^{15}$ Thus replacement rates and saving rates are determined jointly through an iterative process. We first select an arbitrary replacement rate as a starting point and use this replacement rate to determine an initial level of post retirement income and taxes. Then resulting taxes are substituted into equation (6) to obtain an implied saving rate. This saving rate is then substituted into equation (2) to determine a new replacement rate. The process is then iterated until saving and replacement rates converge such that both equations (2) and (6) hold. For our calculations, reported earnings are used to determine taxes using the IRS regulations in place for the 1991 tax year. Taxes are calculated using the standard deductions and married couples are assumed to file jointly.16

\section{Saving and Replacement Rate Results}

Saving and replacement rates are reported for the $\mathbf{6 3 0 6} \mathrm{HRS}$ households who reported positive earned income in 1991. For this group, the median prescribed saving rate for retirement at age 62 in this sample is $16.1 \%$, which corresponds to a replacement rate of $69 \%$. The saving rate drops to a more modest $\mathbf{7 . 3 \%}$ if retirementis delayed to age 65 , with a replacement rate of $78.1 \%$. In other words,

paying $75 \%$ to the surviving spouse.

15 Depending on how the saving is done, the rate of saving may effect either pre-retirement taxes, post-retirement-taxes, or both. For our current calculations we assume saving out of earnings is done on an after-tax basis so it only affects post-retirement taxes; all pension saving is assumed to be pre- tax.

${ }^{16} \mathrm{We}$ do not account for state and local taxes in this version of the paper. To the extent that these differ pre- and post-retirement, this may bias calculated replacement rates. If pre-retirement state and local taxes were higher than post-retirement taxes, this would lead to replacement rates being overstated. 
the later the retirement date, the lower is the prescribed saving rate needed to achieve consumption smoothing.

Figure 3 illustrates the distribution of prescribed saving rates across HRS households, who are alternatively assumed to retire at either age 62 or 65 . Vertical lines represent, respectively, a zero prescribed saving level, and the median of the distribution. Both distributions have large tails below zero, indicating that there is a substantial segment of the population for whom additional savings is not prescribed. For retirement at 62 , almost a third (31\%) of the population is in this zero-or-negative saving category; for retirement at age 65 , some $40 \%$ of the population is estimated to not need any further saving out of earnings beyond accumulation occuring "automatically" through asset appreciation. The peak of the density functions lies to the right of the medians, indicating that the modal, or most commonly prescribed, saving rate is in excess of the mean and median rates.

To further describe the heterogeneity of saving and replacement rate patterns across the HRS sample, we report median values in Table 3 sorted by 1992 wealth and earnings deciles. ${ }^{17}$ One conclusion is that saving rates fall monotonically, and replacement rates rise, with wealth. Another conclusion is that many people are unlikely to be able to save significantly for retirement without making drastic changes in their current consumption levels. For the poorest decile,

${ }^{17}$ Medians are presented instead of means as they give a more accurate representation of typical values within decilcs. Means give curious results because of the presence of outliers; for example, a saving rate value for a household where earnings are at the lower extreme for earnings within a wealth decile might indicate significant dissaving as optimal behavior, possibly to the tune of large multiples of earnings. Averaging that value with others more representative of the subsample would drastically understate the prescribed saving rate for the "typical" household. 
retirement at age 62 would require saving nearly $40 \%$ of pretax earnings. Waiting to retire until 65 would require a more modest, yet still substantial, $27 \%$ of gross earnings. The pattern of saving shortfall extends quite far up the wealth distribution: for each of the first four wealth deciles, prescribed saving rates to age 62 are greater than $20 \%$ of earnings and rates to age 65 are $13 \%$ or higher. By contrast, prescribed saving rates are quite small at the top of the wealth distribution. Those in the wealthiest decile have more than sufficient assets to fund a comfortable retirement, and for some, negative rates indicate that they could dip into their stock of assets to enhance current consumption.18

Another interesting result is that saving patterns switch sign for households in the eighth and ninth wealth deciles, inasmuch as they have positive prescribed saving rates to age 62 , but negative ones to 65 . This indicates that their "optimal" retirement age assuming no further saving might lie somewhere between these two ages. Households towards the middle of the wealth distribution have what are substantial but perhaps not impossible savings targets if they want to retire at age 62, needing-to save 11-18\% of income. This would yield replacement rates of about two-thirds of current earnings. If they continued to work to age 65 , annual saving needs would be cut in half, and replacement rates rise to approximately threequarters of current earnings.

\footnotetext{
13 Of course, it is possible that these households may have a strong bequest motive, in which case the pure replacement model may understate their need and taste for saving. To the extent that there is heterogeneity in the desire to provide bequests, those with a stronger motive likely have accumulatedgreater assets to date and appear here as "over-savers."
} 
A more traditional way of examining replacement and saving rates is to tally these by household income rather than by wealth. The data in Panel B of Table 3 indicate that saving rates are quite negative for the lowest earnings decile: these households would most likely desire to consume out of wealth prior to retirement if they could. In practice, however, such households probably face substantial liquidity constraints in that their wealth is not immediately available for consumption. This would be the case for workers anticipating social security or pension benefits at some future age. ${ }^{19}$

The results in Table 3B also show that prescribed saving rates rise with earnings. Those in the second pay decile need to save a little less than $6 \%$ of income to achieve a replacement rate of $85 \%$ by age 62 . Without additional savings, they could achieve current living standards by retiring some time before reaching 65. For higher earner deciles, double-digit saving is required to retire at 62 with the same relative standard of living. Delaying retirement to age 65 cuts required saving by $7-11 \%$, depending on the family's earnings decile. Similarly, replacement rates fall with earnings but rise with retirement age.

A conclusion that our data on assets and pay highlights is that saving and replacement rates obscures the intertwined relationship between income and wealth. Of course, people with higher earnings also tend to have greater wealth, but this relationship is far from perfect given that the correlation between earnings and initial wealth is only 0.44 . Figure 4 plots prescribed saving rates as a function 
of both earnings and wealth. Median prescribed saving rate values by earningswealth decile pairs are presented for an assumed retirement age of $62 .{ }^{20}$ Figure 5 presents the same information in a contour plot with contour lines at $5 \%$ intervals. These figures illustrate substantial heterogeneity in prescribed saving rates within the same income decile: most households fall along the "diagonal" with wealth increasing with earnings, but there are some households with substantial wealth given their earnings, as well as others whose net wealth seems low in comparison to earnings. The "diagonal" corresponds to the sloped region in Figure 4, running from the bottom left corner to the top right corner of the figure. The closeness of the contour lines in Figure 5 point out that the topology of the surface in Figure 4 is rather steep. In other words, saving rates for households falling along the diagonal are very sensitive to small changes in income or assets.

Descriptive regressions of prescribed saving rates in Table 4 summarize some of the complex multivariate relationships. Coefficients are calculated using median regressions to minimize the effects of extreme observations. For each retirement age, we first relate saving rates as quadratic functions of income and earnings alone, and then add age and other indicator variables indicating whether the household is comprised of a single male or female (versus a married couple), whether individuals in that household have pension wealth, and whether the household owns its own home.

\footnotetext{
19 In addition, their "desire" to consume out of future income may be overstated, inasmuch as earnings exclude non-cash transfers such as food stamps and housing subsidies to the very poor.

20 Plots for age 65 retirement look qualitatively very similar.
} 
All estimated parameters are statistically significant at conventional levels. The estimates suggest that, about the median earnings level of $\$ 33,000$, the effect of an extra $\$ 100$ per year in earnings is to raise the prescribed saving rate by $0.095 \%$ (for retirement by 62 ) or by $0.097 \%$ (at age 65 ). That is, given the median saving rate of $16.1 \%$, raising the rate to $16.195 \%$ implies that $\$ 47.5$ of the additional $\$ 100$ in income would be saved? The effect of $\$ 1000$ more total wealth on prescribed saving is about the same for the median household, but in the opposite direction, causing the saving rate to 62 to fall $0.097 \%$. This translates to approximately $\$ 32$ less in saving in the first year. The coefficients for single men and women reflect the impact of different mortality rates by sex; since women live longer than men, they need to save at a greater rate, and this difference is rather substantial. For esample if age 62 retirement is the target, a woman's prescribed saving rate would exceed the otherwise equivalent man's by $9.1 \%$. The results also show that owning a home and having a employer sponsored pension affect prescribed saving substantially. Since "current" pension wealth and net home values are captured in the initial household wealth variable, these estimated coefficients reflect additions to future wealth - in pensions due to additional service, contributions, and portfolio returns where applicable, and in housing stock due to the paying down of outstanding mortgage debt and home appreciation. The regressions indicate that the presence of a pension reduces prescribed saving by 3-4\% per year, while saving

\footnotetext{
$\because$ Additional savings equals savings on the additional dollars of income plus increase in saving on previous income, i.c. $0.16195^{\star} 100+0.00095^{\star} 33,000$.
} 
done through the home is equivalent to saving an additional $7.6 \%$ out of annual earnings at the median.

\section{Discussion}

We have explored the adequacy of asset holdings in the Health and Retirement Study, a nationally representative survey of older Americans on the verge of retirement. One conclusion is that despite seemingly large accumulations of total retirement wealth, the majority of older households will not be able to maintain current levels of consumption into retirement without additional saving. In particular, the median HRS household has more than $\$ 380,000$ dollars in projected wealth by age 62 , but would still have to save an additional $16 \%$ of earnings to smooth consumption for age 62 retirement.

Another lesson from our analysis is the importance of retirement decisions in generating adequate retirement consumption. Delaying retirement by only three years reduces the saving burden substantially, and allows for a sizable increase in consumption both before and after retirement. In our sample, if retirement were delayed to age 65 , the asset base would total $\$ 421,000$ and prescribed additional saving would be a relatively manageable $7 \%$ of earnings at the median.

We also show that initial and projected assets are distributed quite unevenly across the older population. Therefore conclusions about the median household will conceal extraordinary heterogeneity in saving needs among these households. Small changes in earnings or assets may lead to sizable differences in prescribed saving rates near the median. Average current holdings of the wealthiest HRS 
decile are 45 times those of the poorest decile, and 48 times that of the poorest by age 62. This dispersion arises mainly because of pension and financial wealth, since social security wealth is relatively evenly distributed and housing wealth does not comprise a large fraction of assets for the wealthiest. Assets are more evenly distributed across the other deciles, with the second highest group having 8 times more total wealth than households in the second lowest.

How do our conclusions square with other research on saving patterns? One way to compare them is to see how well prescribed saving rates from our methodology align with actual rates, as in Table 5. Here we tabulate our saving rates for HRS married couples and actual saving rates derived from the 1990 Consumer Expenditure Survey (CES) for the worker group age 50-64 (Palmer 1994). The evidence indicates that actual saving rates are only about a third of the levels prescribed by our calculations. ${ }^{22}$

Another approach is to compare our results to those of Bernheim (1994), who presents after-tax "target" saving rates around twice as large as ours for similarly aged households. For example, his target saving rates for a married couple age 5564 with (without) a pension and earnings of $\$ 30,000$ is $12.1 \%$ (18.1\%); at $\$ 50,000$ it is $19.2 \%$ (24.3\%); and at $\$ 75,000$ it is $22.9 \%$ (28.1\%). Adjusting these rates to reflect saving as a percent of gross income reduces them by approximately $20-30 \%$. However as noted earlier, Bernheim's target rate calculations omit housing wealth, 
which if included would narrow the difference between our prescribed saving rates substantially?

A third way to assess the comparability of our results with those in the literature is to compare projected replacement rates. Figure 6 shows our HRS target replacement rates with those generated using the 1990 CES (Palmer 1994), and some differences emerge. The HRS profiles both fall with earnings, in contrast to those derived from the CES data which are flatter and rise for higher incomes. Part of the difference between our results and Palmer's is that his method implicitly assumes observed saving rates are optimal. To the extent that retirement income is not provided by social security, pensions, or existing assets, and needs to be provided by additional saving, this will lead to Palmer's replacement rates overstating actual replacement rates. ${ }^{24}$ Palmer's research also assumes an age 65 retirement age . We also note that the age-65 replacement rate for the HRS sample is substantially above the age 62 rate, illustrating the importance of retirement ages in the methodology. If retirement occurs earlier, and empirical evidence suggests it does, this is further cause to believe that average actual replacement rates fall below those estimated by Palmer.

\footnotetext{
23 Another way to think about housing wealth is that mortgage payments have both an investment component and a consumption component. The investment component recognizes the purchase of the house as an investment in a tangible asset. The consumption component represents what the homeowner would pay for housing services, or for the non-homeowner, rent. Since shelter is a large consumption expense, paying off the mortgage represents a substantial decrease in income required to cover consumption needs or a prefunding of later housing consumption.

24 Schieber (1996) offers additional criticism of Palmer's methodology arguing that that are upwardly biased.
} 
One question we have not yet explored in any depth is why observed saving patterns appear to fall short of target saving benchmarks, both ours and others such as Bernheim's. One possible answer is that some households are simply too poor to defer consumption, but this appears unlikely for those other than the poorest in our sample. Other possible explanations center around informational issues, for example, households may simply underestimate their likely life expectancy in retirement, though recent research by Hurd and McGarry ( 1995) suggests that HRS respondents have quite reasonable forecasts of survival probabilities into old age. An additional hypothesized explanation is that people discount the future to varying degrees and some may do so very heavily. The rich set of standard and experimental questions in the HRS and future information provided by these households may provide clues to discovering the answers. 


\section{Data Appendix: Wealth Projections Using the Health and Retirement Study}

In this Appendix we describe briefly the methods used to project elements of retirement wealth forward to age 62 and 65 for the HRS sample described in the text.

\section{A. Social Security Wealth}

Social security wealth measures are contained in the Earning and Benefits File (EBF), a restricted dataset available under controlled access conditions and described in Mitchell, Olson and Steinmeier (1996). This file reports covered earnings under the social security law and estimated old-age and disability benefit amounts for HRS respondents who gave permission for administrative data to be linked to their survey responses. Retirement benefits are calculated based on earnings through 1991 and projected earnings to age 62 (the eligibility age for early retirement benefits), and also to the social security normal retirement ages (65 for most HRS participants). In addition the EBF file indicates household wealth figures which for married couples includes spouse and survivor benefits.

Assumptions used to compute these benefit amounts are consistent with those used by the Social Security Administration (SSA) under its "intermediate assumptions" scenario outlined by the Social Security Trustees to forecast the system's fiscal status. Details of the calculations of Social Security benefit amounts, present values, and other available variables are described in Mitchell, et al. (1996). Of the 7607 HRS households, 4334 had useable Social Security wealth from the EBF file.

For those households where earnings records were not available, values were imputed using HRS dataset. Separate regression models were constructed for married couples and households with single individuals. The coefficients of the prediction model were estimated using the sample for which EBF social security wealth was available. Regressor variables used were those common to all households in the HRS dataset and include male earnings, female earnings, financial net wealth, net housing wealth, respondent age, spouse's age, a dummy for white primary respondents, and a dummy for single female, with the log of social security wealth as the dependent variable. Estimated coefficients were used out of sample to estimate social security wealth for those households not appearing in the EBF.

\section{B. Pension Wealth}

The Institute for Survey Research (ISR) at the University of Michigan asked HRS respondents covered by employer-provided pensions for permission to contact their employers for information about these pension plans. Having obtained the names and addresses of the employers, ISR requested a pension plan Summary Plan Description (SPD) for each worker's current and past plans, and followed up with requests for the SPD at the US Department of Labor where employer. supplied documents were not obtained. The SPDs were then coded using a format developed at ISR, and combined with a special software program developed by Curtain and others (1997). The software uses information collected from the SPDs to calculate benefit streams based on respondents'salary profiles and service, at alternative retirement ages. Vested terminated benefits as well as benefits available from current pension plans are included in the analysis in this paper. The employer sponsored pension information and pension provider software are in the developmental phase and can currently be accessed only under restricted conditions.

Mortality, interest rate, inflation, and wage growth valuation assumptions are consistent with those used by the Social Security Administration in its annual reporting to Congress. For defmed benefit plans, present values are calculated assuming a $2.3 \%$ real interest rate and a $4.0 \%$ inflation assumption (implying a $6.3 \%$ nominal discount rate). For defined contribution plans, real returns on contribution balances are assumed to be $4.0 \%$ annually ( $8.0 \%$ nominal). The same assumption is used for calculating present values. The pension provider software does not permit different assumptions for contribution growth and discounting, but we feel it is appropriate to use the higher discount rate in the defined contribution pensions plans due to the greater uncertainty of future benefit levels. Defined benefit plans sponsored by HRS participants' current employers are assumed to pay cost of living adjustments of half the inflation rate, mirroring historical practice. Benefits from previous employers and defmed contribution plans are assumed to have no cost of 
living adjustment. The percentage of plans for which we were able to use the ISR software to estimate the present value of plan benefits varied by plan type, but was generally between 60\%$70 \%$.

For those households where pension plan data were not generated by the ISR software, values were imputed using I-IRS dataset. Separate regression models were constructed for each pension type. Regressor variables used were those common to all households in the HRS dataset and include earnings, age, service in the plan, dummies industry, job description, race, sex, and union status. The log of pension wealth is the dependent variable. Estimated coefficients were used out of sample to estimate pension wealth for those households with missing pension data.

\section{Housing Wealth}

Net housing wealth reported in the HRS is the value of owner-occupied primary housing less debt owed on the property. The projected net value we use in this study is derived as the projected market value of the housing less projected debt. We assume that the market value of housing assets is constant in real dollars, or in other words, the increase in home value is equal to the assumed rate of inflation. Projecting debt is more complicated, as will be explained.

The I-IRS provides information on first mortgages, second mortgages, home equity loans, and lines of credit against housing equity. To roll forward debt we need a) the outstanding balance on the mortgage or other debt, b) the payments and frequency of payments on that debt, and c) the interest rate on the debt. The HRS provides the first two of these three which necessitates the use of alternative sources for the mortgage rate.

Given the purchase date of the house, a datum reported by HRS respondents, we use historical interest rates as prosies for current rates. However this ignores the possibility that the homeowner refinanced his mortgage. We know that interest rates fluctuate over time, and a common "rule of thumb" has the mortgage holder refinance when rates drop by more than 200 basis points (2\%). Therefore, for esample, using the May 1980 average 30 year mortgage rate for a house purchased in May 1980 would likely overstate the actual interest costs for many if not most households. A different approach would be to take the purchase price of the house reported in the HRS. the payment amount, and some assumption regarding the term of the mortgage (e.g.: assume a 30 year fixed-rate mortgage). This has the problem that many households' mortgage payments include their property tases, homeowners insurance premiums, or both. Imputing mortgage interest rates from the raw payments would bias upward the derived mortgage interest rates.

Data from another survey mitigates some of these problems. The American Housing Survey (AHS; 1993) provides interest rate data for houses in its sample. From this source, we calculate a series of actual mortgage rates paid by averaging conditional on year of home purchase and use these to roll forward first mortgage debt. Analysis of these rates as opposed to issue rates indicate that they embed substantial refinancing for periods such. as the early $1980^{\circ}$ s. For years prior to 1953 where data are thin, or where HRS households do not indicate a year of purchase, we use the average mortgage interest rate for the sample, approximately $8.5 \%$.

The AHS also has information on tax and insurance payments. These in addition to tax payment information contained in the HRS are used to calculate an effective mortgage payment, or the amount of the mortgage that actually services the debt. HRS households indicate whether given payments include tases, insurance, both, or neither. When taxes are given, these are used to reduce mortgage payments. When they are not the average rate of tax as a percent of payment as calculated from the AI-IS is used instead. A similar procedure is used for insurance payments when they are included in mortgage payments. The AI-IS derived values for taxes and insurance are $18.11 \%$ and $5.90 \%$ of mortgage payments, respectively.

For second mortgages and home equity loans the HRS does not contain information on year of issue. These amounts are therefore projected forward using the average rate on such debt from the AIS, approximately $9.5 \%$.

Missing observations on mortgage payment amounts are imputed assuming a 30 year fixed mortgage at the rate associated with the purchase year when purchase year and price are available. When this information is unavailable, it is assumed that the payments are such that the mortgage 
is paid off at age 70. For missing secondary debt, a IO-year term is assumed to pay off the remaining balance. There are 123,47 , and 36 missing payments that are imputed in this manner, respectively

\section{Other Financial Wealth}

Other financial wealth includes such assets as savings, investments, business assets, and non-residential real estate less outstanding debt not related to housing. Asset values in 1992 are provided by HRS respondents. To obtain projected net financial assets, as noted in the text, we project individual components of this asset category separately. That is, equity components of assets are projected in line with historical equity returns, bond returns are used to project fixed income holdings, and personal business assets are projected using the equity rate of return. Assumed growth rates are geometric averages of real returns over the period 1926-'95 as calculated using the Stocks, Bonds, Bills, and Inflation series from Ibbotson Associates.

The components of net financial wealth as tabulated in the HRS and the rates used to project them:

- Vehicle and RV Wealth - Depreciated over ten years using straight line depreciation.

- Checking, Savings, money market accounts - Real t -bill rate $(0.5 \%)$

- CD's, savings bonds, T-bills - Real t-bill rate $(0.5 \%)$

- IRA's and Keough Accts. -50/50 Corporate Bonds/Stocks (2.3\%/7.2\%)

- Stocks, Mutual Funds - Stocks (7.2\%)

- Business Equity - Stocks (7.2\%)

- Other Assets, Real Estate, Second Home - held constant in real terms

- less other debt, second home debt - held constant since we lack other information to estimate changes in value 


\section{References}

Bernheim, B. Douglas, 1992. "Is the Baby Boom Generation Preparing Adequately for Retirement?" Technical Report. Princeton, N. J., Merrill Lynch.

Bernheim, B. Douglas, 1994. "The Merrill Lynch Baby Boom Retirement Index" Summary Report Merrill Lynch, 1994.

Case, Karl E., 1994. "Land Prices and House Prices in the United States". In Housing Markets in the United States and Japan, Y. Noguchi and J.M. Poterba, eds., Chicago: University of Chicago Press.

Curtin, Richard T. 1997. "Employer Sponsored Pension Plan Documentation: Pension Estimation Program Software Documentation". University of Michigan, Ann Arbor. Updated April 1997.

Congressional Budget Office, 1993. "Baby Boomers in Retirement: An Early Perspective'. Washington, D.C., U.S. Government Printing Office.

Gokhale, Jagadeesh, Laurence J. Kotlikoff, and John Sabelhaus, 1996. "Understanding the Postwar Decline in U.S. Saving: A Cohort Analysis", Brookings Papers on Economic Activity 1, pp.315-407.

Gustman, Alan L., Olivia S. Mitchell, Andrew A. Samwick, and Thomas L. Steinmeier, 1997. "Pension and Social Security Wealth in the Health and Retirement Study". NBER Working Paper, February.

Hurd, Michael D. and Kathleen McGarry. "Evaluation of the Subjective Probabilities of Survival in the Health and Retirement Study," Journal of Human Resources 30, Supplement 1995, pp. S268s292.

Ibbotson Associates, 1996. Stocks, Bonds, Bills, and Inflation: 1996 Yearbook. Chicago, IL.

McGill, Dan M., Kyle N. Brown, John J. Haley, and Sylvester J. Schieber, 1996. Fundamentals of Pricate Pensions, Seventh Edition. Philadelphia: University of Pennsylvania Press.

Mitchell, Olivia S. and James F. Moore, 1997. "Retirement Wealth Accumulation and Decumulation: New Developments and Outstanding Opportunities". Wharton Financial Institutions Center Working Paper, The Wharton School, Philadelphia, March.

Mitchell, Olivia S., Jan Olson, and Thomas Steinmeier, 1996. "Construction of the Earnings and Benefits File (EBF) for Use with the Health and Retirement Study'. NBER Working Paper 5707. Cambridge, Mass.

Palmer, Bruce A. 1988. The Impact of Tax Reform on Wage Replacement Ratios. Atlanta: Georgia State University, Center for Risk Management and Insurance Research.

Palmer, Bruce A. 1991. 1991 Georgia State University/Alexander \& Alexander Consulting Group RETIRE Project Report. Atlanta: Georgia State University, Center for Risk Management and Insurance Research.

Palmer, Bruce A 1993.1993 Georgia State University/Alexander \& Alexander Consulting Group RETIRE Project Report. Atlanta: Georgia State University, Center for Risk Management and Insurance Research. 
Palmer, Bruce A. 1994. "Retirement Income Replacement Ratios: An Update". Benefits Quarterly. Second Quarter: 59-69.

Schieber, Sylvester J. 1996. "Conceptual and Measurement Problems in Contemporary Measures of Income Needs in Retirement". Benefits Quarterly. Second Quarter: 56-68.

Social Security Advisory Council (SSAC), Report of the 1994-l 996 Advisory Council on Social

Security, Volumes I and II, Washington, D.C.: Social Security Administration, 1996.

U.S. Department of Commerce, Bureau of the Census, 1994. American Housing Survey, 1991: National File, Washington, D.C. 
Table 1: Mean Value and Composition of HRS Wealth (1992) by Wealth Decile

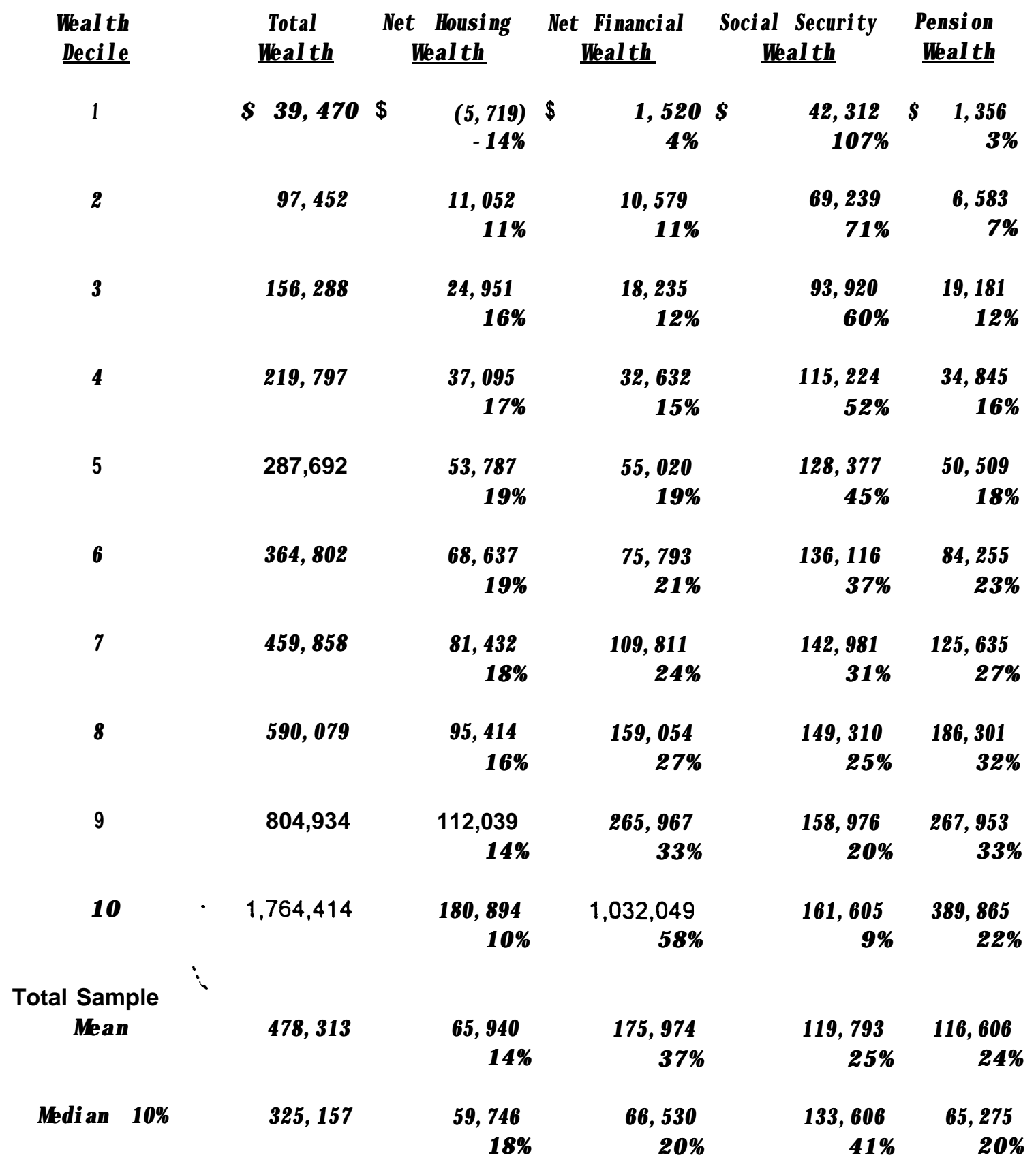

All values in 1992 dollars and calculated using HRS sampling weights. 
Table 2: Mean Value of HRS Wealth (1992 and Projected) by Wealth Decile

\begin{tabular}{|c|c|c|c|}
\hline $\begin{array}{l}\text { Weal th } \\
\text { Decile }\end{array}$ & $\begin{array}{l}\text { Current } \\
\text { Weal th } \\
\end{array}$ & $\begin{array}{l}\text { Proj ect ed } \\
\text { Weal th at } \\
\text { Ade } 62\end{array}$ & $\begin{array}{l}\text { Project ed } \\
\text { Weal th at } \\
\text { Aqe } 65\end{array}$ \\
\hline 1 & $\$ 39,470$ & $\$ 43,804$ & $\$ 49,031$ \\
\hline 2 & 97,452 & 109,578 & 121,123 \\
\hline 3 & 156,288 & 182,494 & 202,946 \\
\hline 4 & 219,797 & 256,636 & 283,184 \\
\hline 5 & 287,692 & 338,153 & 372,701 \\
\hline 6 & 364,802 & 429,253 & 471,308 \\
\hline 7 & 459,858 & 543,397 & 595,408 \\
\hline 8 & 590,079 & 699,681 & 763,756 \\
\hline 9 & 804,934 & 944,894 & $1,030,054$ \\
\hline 10 & $1,764,414$ & $2,117,052$ & $2,362,963$ \\
\hline
\end{tabular}

\section{Total Sample}

$\begin{array}{lrrr}\text { Mean } & 478,313 & 566,431 & 625,066 \\ \text { - Housing } & 65,940 & 76,410 & 80,507 \\ \text { - Financi al } & 175,974 & 205,653 & 228,133 \\ \text { - Social Security } & 119,793 & 128,712 & 142,018 \\ \text { - Pensi on } & 116,606 & 155,656 & 174,408 \\ & & & \\ \text { Median 10\% } & 325,157 & 382,678 & 420,537 \\ \text { - Housing } & 59,746 & 71,097 & 75,047 \\ \text { - Financi al } & 66,530 & 71,004 & 77,175 \\ \text { - Social Security } & 133,606 & 143,864 & 160,824 \\ \text { - Pensi on } & 65,275 & 96,713 & 113,491\end{array}$


Table 3: Median Prescribed Saving and Replacement Rates

A. By 1992 Weal th Decile

\begin{tabular}{|c|c|c|c|c|c|}
\hline \multirow[b]{2}{*}{$\begin{array}{l}\text { Wealth } \\
\text { Decile }\end{array}$} & \multirow{2}{*}{$\begin{array}{c}\text { Medi an } \\
\text { Househol d } \\
\text { Net Weal th } \\
\end{array}$} & \multicolumn{2}{|c|}{ Saving to Age 62} & \multicolumn{2}{|c|}{ Saving to Age 65} \\
\hline & & $\begin{array}{l}\text { Saving } \\
\text { Rate }\end{array}$ & $\begin{array}{l}\text { Repl acement } \\
\text { Rat e }\end{array}$ & $\begin{array}{l}\text { Saving } \\
\text { Rate }\end{array}$ & $\begin{array}{l}\text { Repl acement } \\
\text { Rate }\end{array}$ \\
\hline 1 & 43,900 & 38. $3 \%$ & 48. $7 \%$ & $26.9 \%$ & $58.8 \%$ \\
\hline 2 & 97,600 & $32.7 \%$ & $52.5 \%$ & $21.3 \%$ & $61.7 \%$ \\
\hline 3 & 156,600 & $26.8 \%$ & 58. $3 \%$ & $15.5 \%$ & $67.7 \%$ \\
\hline 4 & 220,500 & $24.0 \%$ & $60.3 \%$ & 13. $6 \%$ & $69.1 \%$ \\
\hline 5 & 286,500 & 18. $1 \%$ & $67.5 \%$ & $8.9 \%$ & 76. $1 \%$ \\
\hline 6 & 364,000 & 17. $0 \%$ & $67.0 \%$ & 8. $5 \%$ & $75.6 \%$ \\
\hline 7 & 458,900 & 11. $4 \%$ & 73. $3 \%$ & 3. $0 \%$ & $81.4 \%$ \\
\hline 8 & 587,800 & 7. $0 \%$ & 78. $9 \%$ & $-0.9 \%$ & $87.1 \%$ \\
\hline 9 & 792,600 & $1.0 \%$ & 88. $3 \%$ & $-6.1 \%$ & $96.6 \%$ \\
\hline 10 & $1,363,000$ & $-25.4 \%$ & $126.8 \%$ & $-35.0 \%$ & 137. $1 \%$ \\
\hline Total & & & & & \\
\hline Sample & 325,000 & 16. $1 \%$ & $69.0 \%$ & 7. $3 \%$ & 78. $1 \%$ \\
\hline
\end{tabular}

B. By 1992 Earnings Decile

\begin{tabular}{|c|c|c|c|c|c|}
\hline \multirow[b]{2}{*}{$\begin{array}{c}\text { Earnings } \\
\text { Decile }\end{array}$} & \multirow[b]{2}{*}{$\begin{array}{l}\text { Househol d } \\
\text { Earnings }\end{array}$} & \multicolumn{2}{|c|}{ Saving to Age 62} & \multicolumn{2}{|c|}{ Saving to Age 65} \\
\hline & & $\begin{array}{l}\text { Saving } \\
\text { Rate }\end{array}$ & $\begin{array}{l}\text { Repl acement } \\
\text { Rate }\end{array}$ & $\begin{array}{l}\text { Saving } \\
\text { Rate }\end{array}$ & $\begin{array}{l}\text { Repl acement } \\
\text { Rate }\end{array}$ \\
\hline 1 & 4,500 & $-122.5 \%$ & $218.8 \%$ & $-132.8 \%$ & $227.8 \%$ \\
\hline 2 & 11,930 & $5.9 \%$ & $84.8 \%$ & $-4.6 \%$ & $93.4 \%$ \\
\hline 3 & 17,500 & $13.5 \%$ & 75. $1 \%$ & 2. $2 \%$ & $84.6 \%$ \\
\hline 4 & 24,000 & $15.1 \%$ & 73. $3 \%$ & 4. $3 \%$ & 82. $2 \%$ \\
\hline 5 & 30,000 & $18.0 \%$ & $68.6 \%$ & 7. $3 \%$ & 77. $8 \%$ \\
\hline 6 & 37,000 & $16.7 \%$ & $67.1 \%$ & 8. $1 \%$ & $75.6 \%$ \\
\hline 7 & 45,000 & $17.0 \%$ & $64.3 \%$ & $9.8 \%$ & $73.6 \%$ \\
\hline 8 & 54,050 & $18.4 \%$ & $62.3 \%$ & $10.6 \%$ & 72. $0 \%$ \\
\hline 9 & 70,000 & $20.3 \%$ & $60.2 \%$ & 12. $6 \%$ & $69.8 \%$ \\
\hline 10 & 102,000 & $23.7 \%$ & $57.8 \%$ & $16.5 \%$ & $67.6 \%$ \\
\hline lotal & & & & & \\
\hline Sampl e & 33,000 & 16. $1 \%$ & $69.0 \%$ & 7. $3 \%$ & 78. $1 \%$ \\
\hline
\end{tabular}


Table 4: Descriptive Regression of Prescribed Saving Rates

\begin{tabular}{|c|c|c|c|c|}
\hline \multirow[b]{2}{*}{ Househol d Earni ngs } & \multicolumn{2}{|c|}{$\begin{array}{l}\text { Prescribed Saving } \\
\text { Rate to Age } 62\end{array}$} & \multicolumn{2}{|c|}{$\begin{array}{l}\text { Prescribed Saving } \\
\text { Rate to Age } 65\end{array}$} \\
\hline & $\begin{array}{r}1.0 \mathrm{l} \mathrm{E}-05 \\
89.46\end{array}$ & $\begin{array}{r}1.03 E-05 \\
125.94\end{array}$ & $\begin{array}{r}1.09 E-05 \\
89.14\end{array}$ & $\begin{array}{r}1.05 E-05 \\
101.37\end{array}$ \\
\hline $\begin{array}{l}\text { Ear ni ngs Squared } \\
\div 10,000\end{array}$ & $\begin{array}{r}-18 \mathrm{EE}-07 \\
-66.24\end{array}$ & $\begin{array}{r}-1.22 E-07 \\
-95.43\end{array}$ & $\begin{array}{r}-1.35 E-07 \\
-69.76\end{array}$ & $\begin{array}{r}-1.24 \mathrm{E}-07 \\
-76.85\end{array}$ \\
\hline $\begin{array}{l}\text { Total Househol d } \\
\text { Weal th }\end{array}$ & $\begin{array}{r}-9.93 E-07 \\
-93.44\end{array}$ & $\begin{array}{c}-9.73 E-07 \\
-119.81\end{array}$ & $\begin{array}{r}-1.01 \mathrm{E}-06 \\
-87.07\end{array}$ & $\begin{array}{r}-9.60 E-07 \\
-93.79\end{array}$ \\
\hline $\begin{array}{l}\text { Weal th Squar ed } \\
\div 100,000\end{array}$ & $\begin{array}{r}9.71 \mathrm{E}-09 \\
45.75\end{array}$ & $\begin{array}{r}9.18 \mathrm{E}-09 \\
57.93\end{array}$ & $\begin{array}{r}9.12 \mathrm{E}-09 \\
39.34\end{array}$ & $\begin{array}{r}7.27 \mathrm{E}-09 \\
36.29\end{array}$ \\
\hline Single Male & & $\begin{array}{r}-0.0733 \\
-9.06\end{array}$ & & $\begin{array}{r}-0.1304 \\
-12.77\end{array}$ \\
\hline Si ngl e Femal e & & $\begin{array}{r}0.0181 \\
3.02\end{array}$ & & $\begin{array}{r}-0.0458 \\
-6.04\end{array}$ \\
\hline $\begin{array}{l}\text { Pri mary Respondent } \\
\text { Age }\end{array}$ & & $\begin{array}{r}0.00402 \\
9.11\end{array}$ & & $\begin{array}{r}0.00152 \\
2.72\end{array}$ \\
\hline Have Pensi on & & $\begin{array}{r}-0.0341 \\
-7.18\end{array}$ & & $\begin{array}{r}-0.0389 \\
-6.49\end{array}$ \\
\hline Own Home & & $\begin{array}{r}-0.0767 \\
-13.08\end{array}$ & & $\begin{array}{l}-0.0764 \\
-10.307\end{array}$ \\
\hline Constant & $\begin{array}{l}0.131 \\
24.87\end{array}$ & $\begin{array}{r}-0.0111 \\
-0.442\end{array}$ & $\begin{array}{r}0.0127 \\
2.217\end{array}$ & $\begin{array}{r}0.0415 \\
1.3\end{array}$ \\
\hline $\begin{array}{l}\text { Pseudo } R^{2} \\
\mathbf{N} \\
\text { Wt } d \text {. Sum of Absol ute } \\
\text { Devi ati ons }\end{array}$ & $\begin{array}{r}0.0862 \\
6306\end{array}$ & $\begin{array}{r}0.0893 \\
6306\end{array}$ & $\begin{array}{r}0.0846 \\
6306\end{array}$ & $\begin{array}{r}0.0884 \\
6306\end{array}$ \\
\hline
\end{tabular}

Note: Coefficients estimated using median regressions to minimize effects of extreme outliers. Coefficients calculated using HRS household sampling weights. T-statistics appear bel ow estimated coefficient values. 
Tabl e 5: Compari son of Prescribed Saving Rates from HRS and Actual Rates from CES

\section{Househol d \\ Earni nas}

20,000

30,000

40,000

50,000

60,000

70,000

80,000

90,000

\begin{tabular}{ll} 
HRS Prescribed Rates \\
\hline$\underline{\text { Age } 2}$ & $\underline{\text { Aae } 65}$
\end{tabular}

6. $0 \%$

16. $8 \%$

17. $7 \%$

17. $9 \%$

20. $2 \%$

20. $3 \%$

21. $1 \%$

20. $5 \%$
$-1.9 \%$

8. $5 \%$

10. $0 \%$

11. $1 \%$

13. $1 \%$

13. $5 \%$

14. $2 \%$

13. $3 \%$
Act ual CES

Savi na Rates

2. $3 \%$

2. $8 \%$

3. $3 \%$

3. $7 \%$

4. $1 \%$

4. $5 \%$

5. $0 \%$

5. $4 \%$

Prescribed saving rates calculated using HRS (1992); Median values given for married couples with earnings within \pm 5000 of reported earnings using HRS household sampling weights.

CES Saving rates taken from Palmer's (1994) calculations using the 1990 Consumer Expenditure Survey for respondents age 50-64. Rates are adjusted to reflect saving asa percentage of total earnings. 


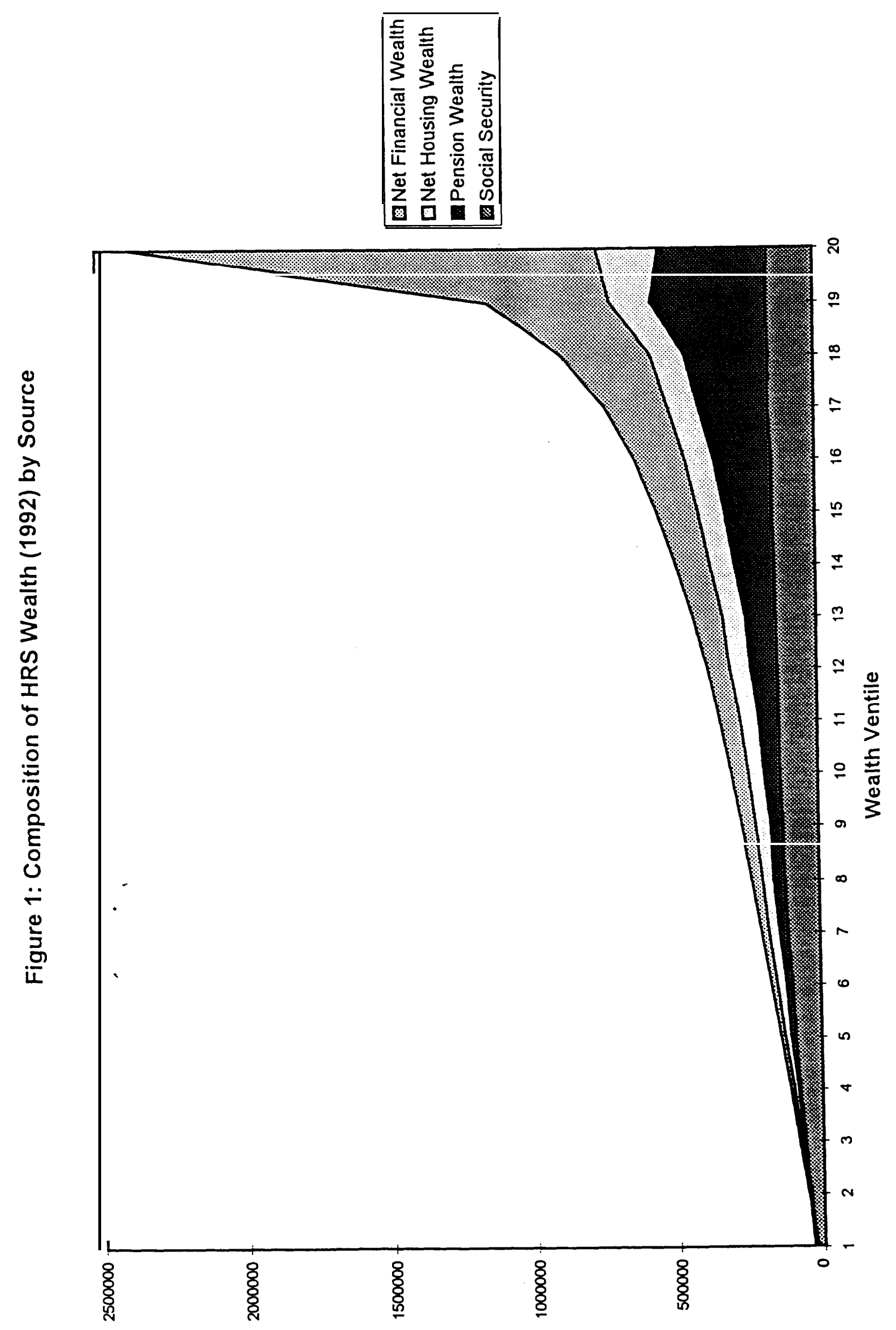




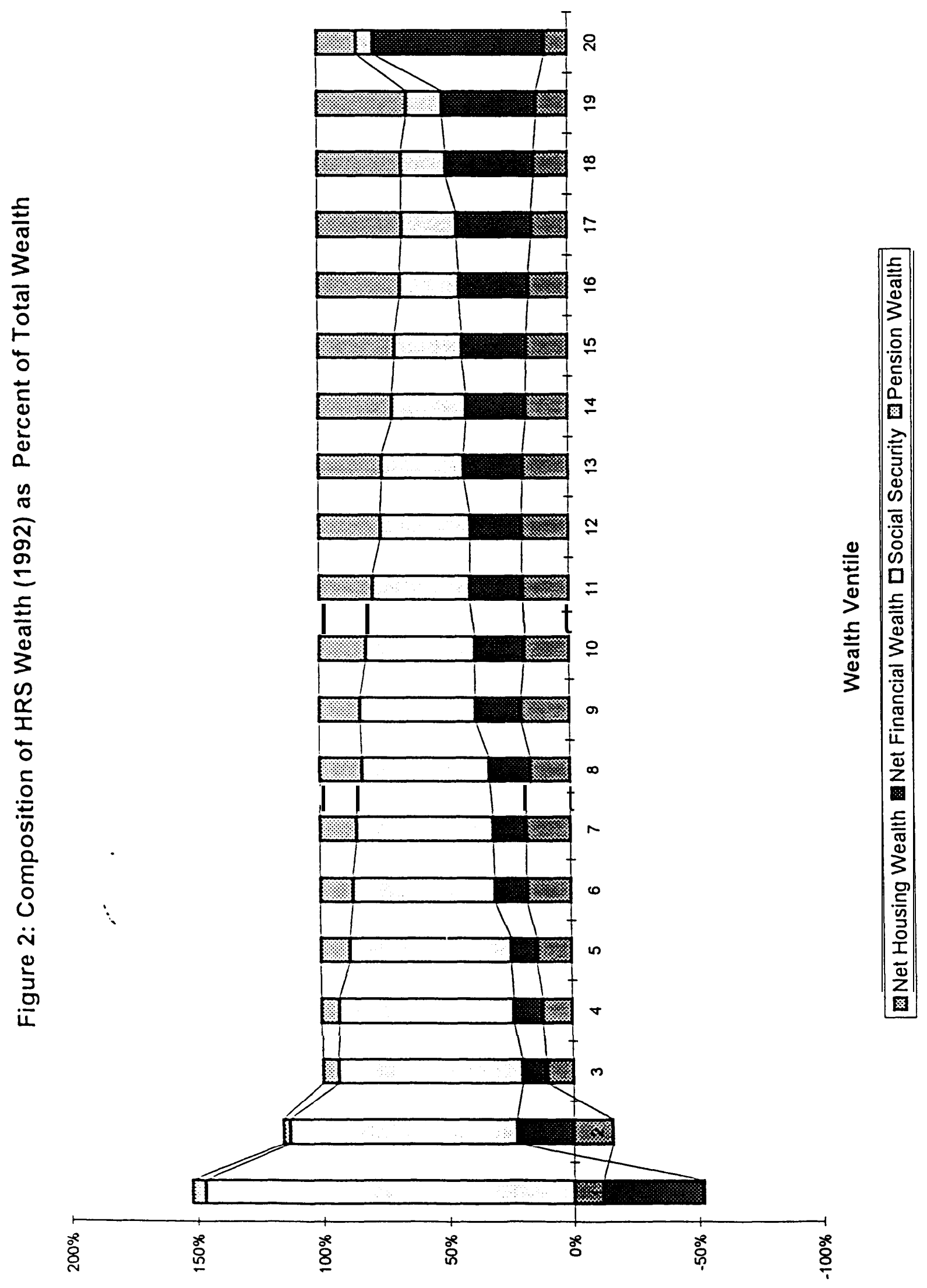


Figure 3. Distribution of Prescribed Saving Rates

\section{A. Retirement at age 62}

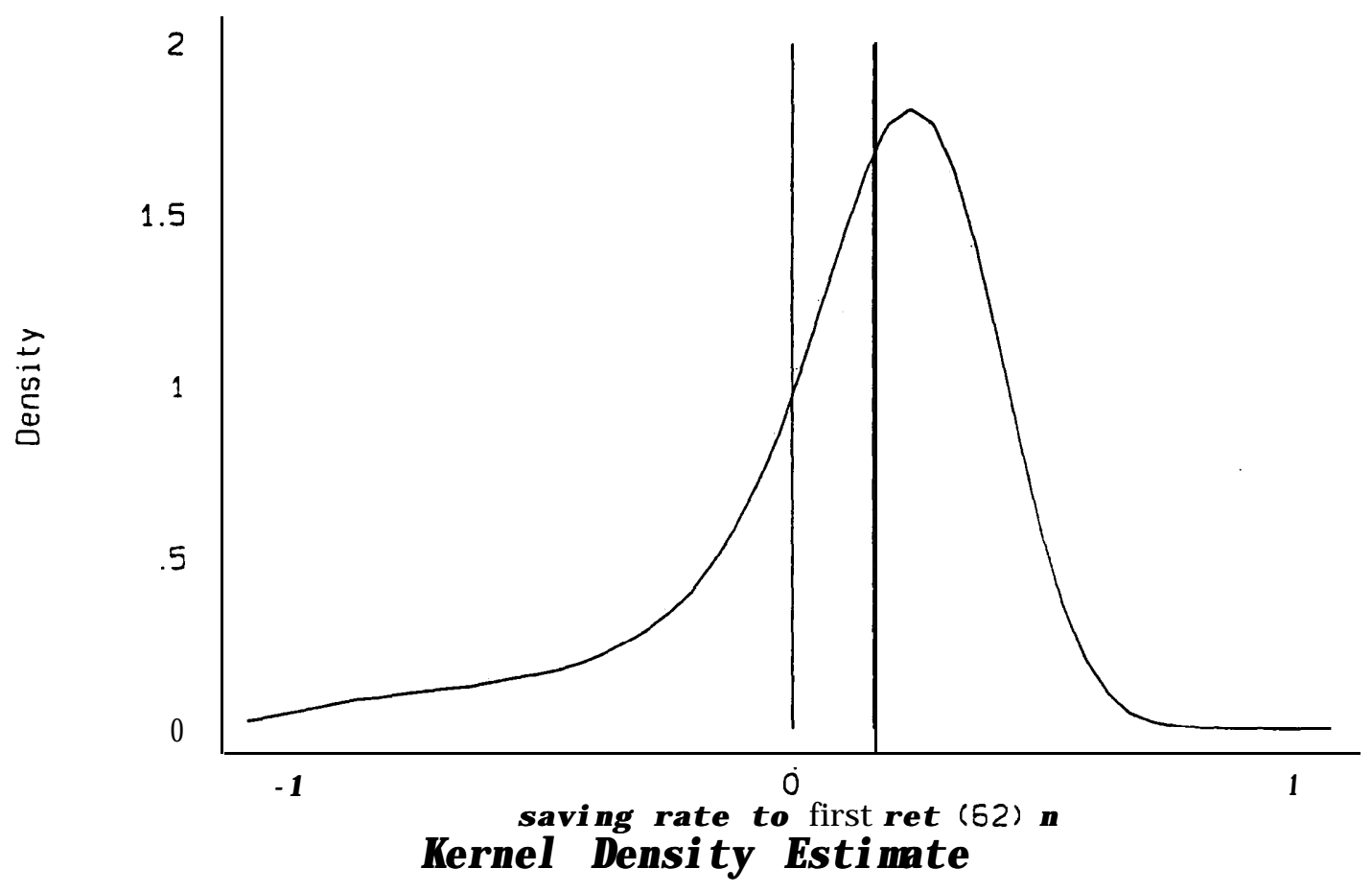

B. Retiremcent at Age 65

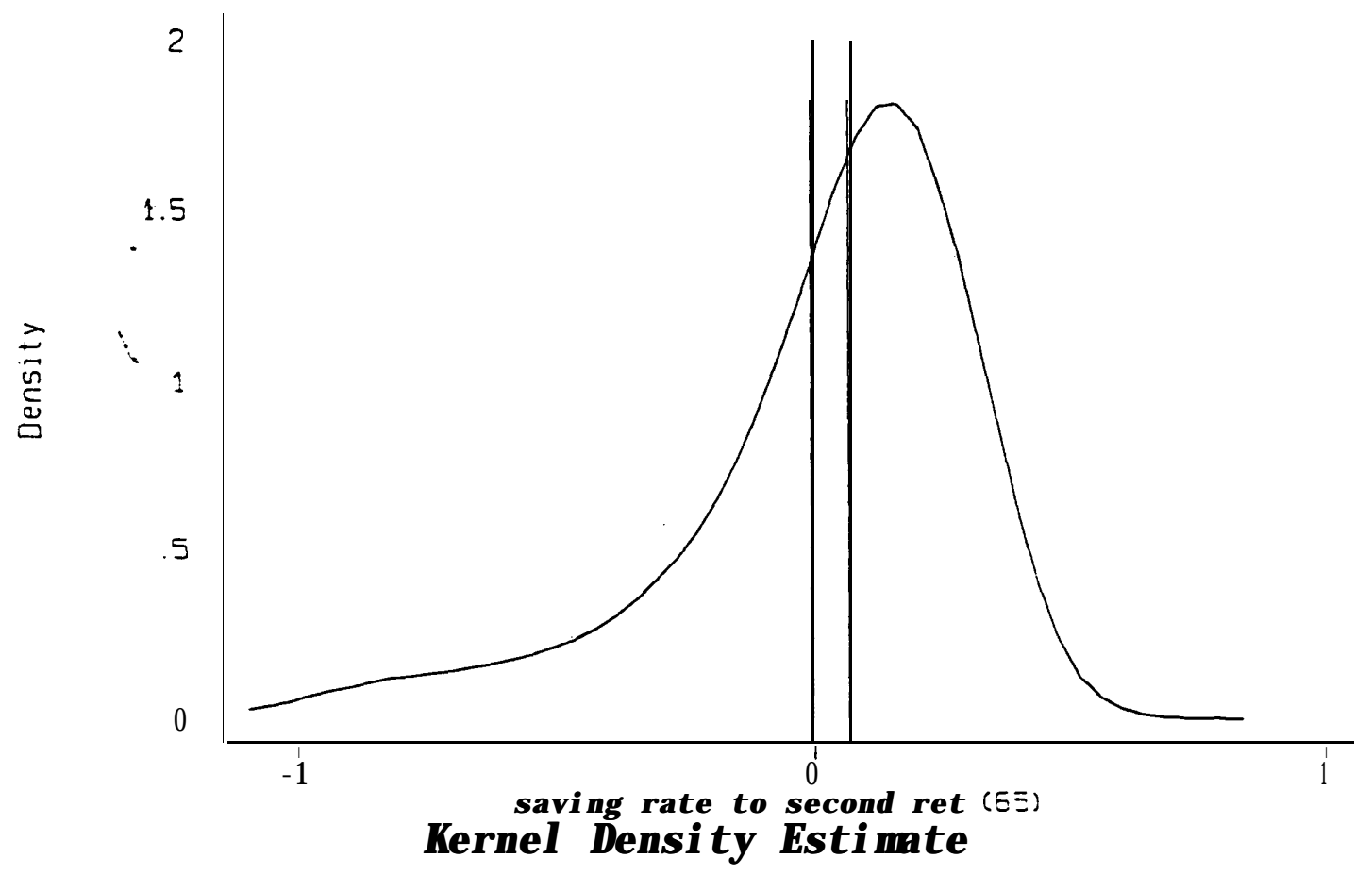


Figure 4. Prescribed Saving Rates by 1992 Earnings and Wealth

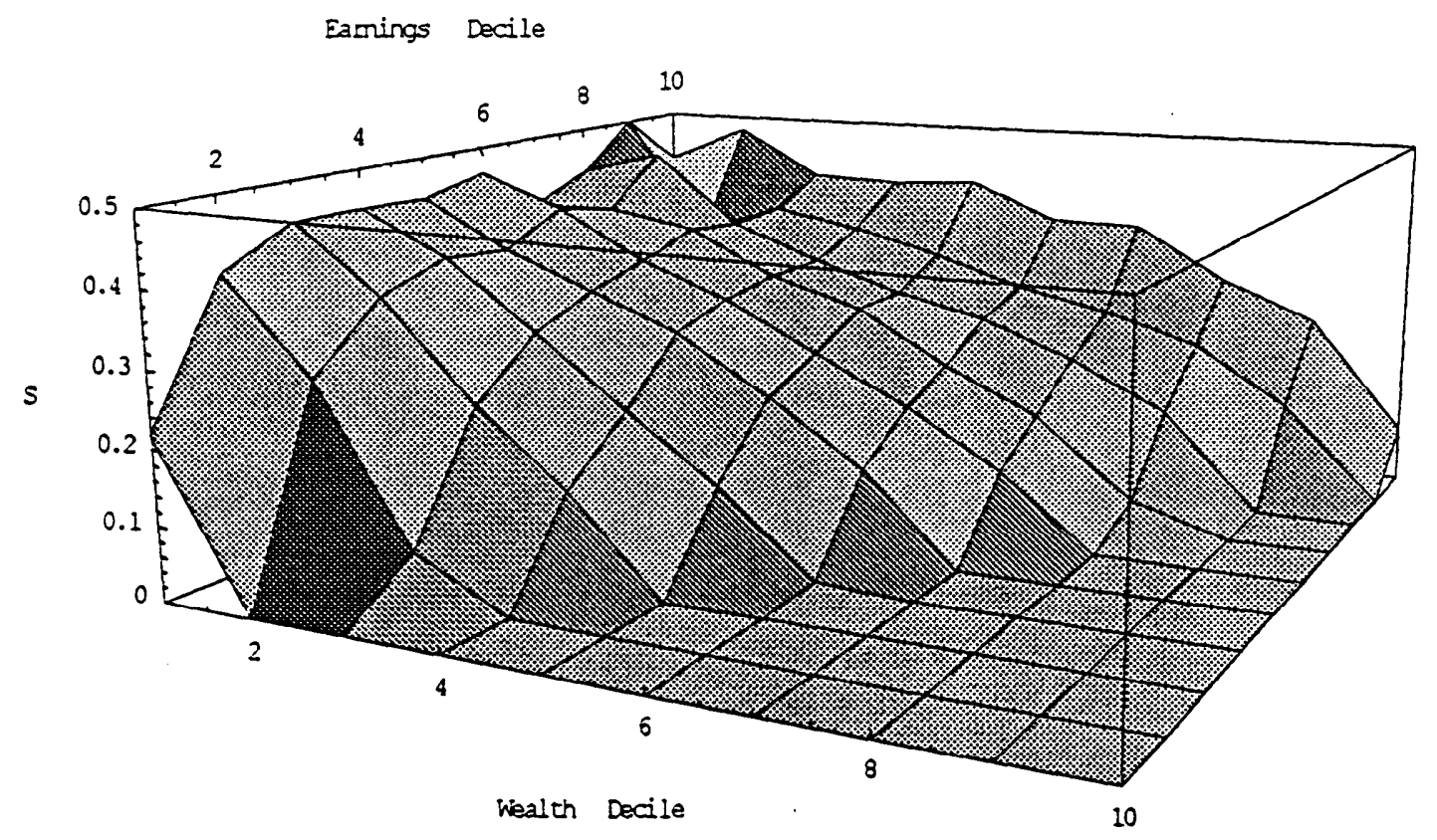

Plot of prescribed saving rates for retirement at age 62. Values are the median prescribed saving rate for each earnings- wealth decile pair. 
Figure 5. Contour Plot of Prescribed Saving Rates to Age 62

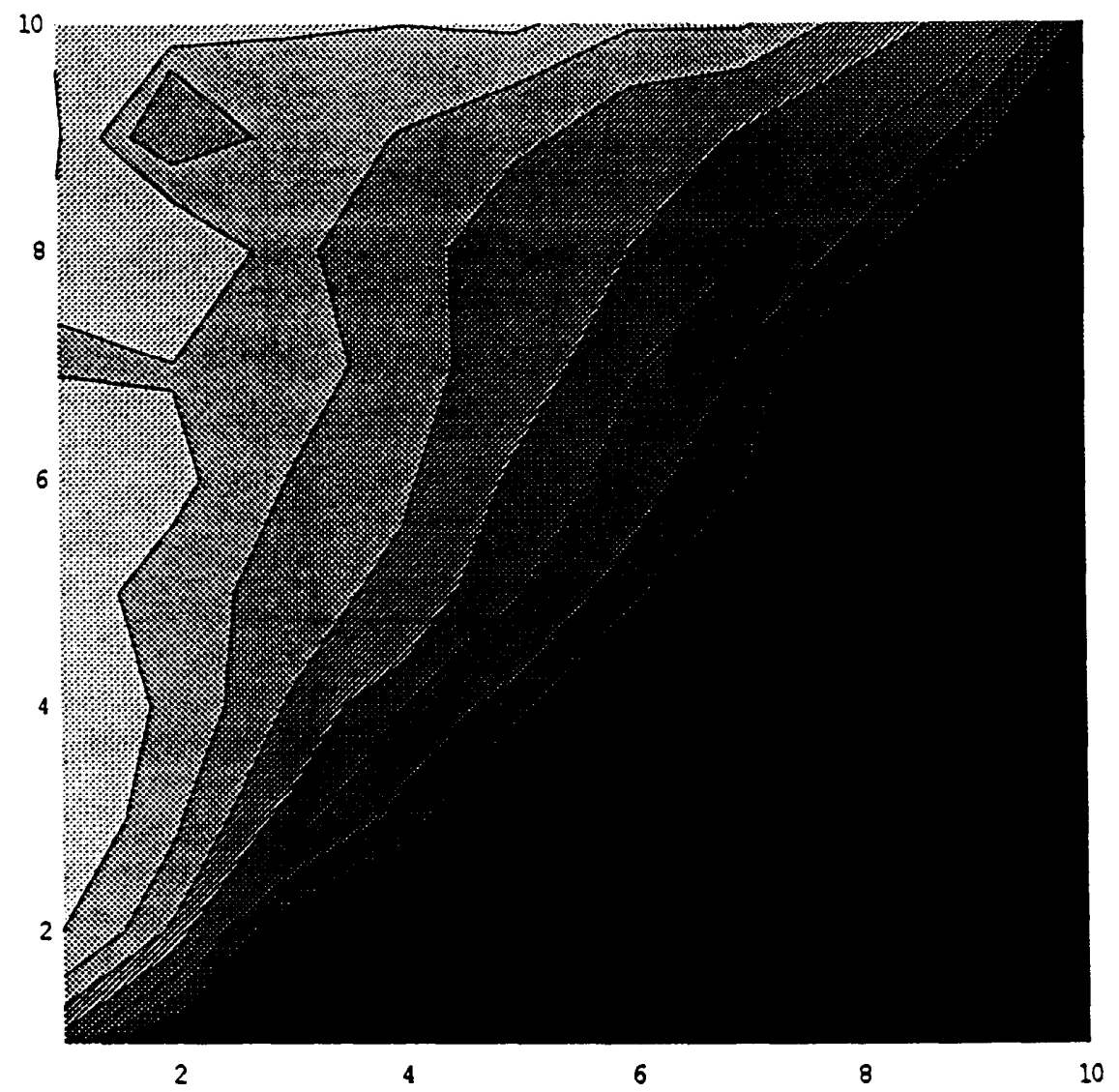

Contour plot of prescribed saving rates for retirement at age $62 . \mathrm{X}$-axis is wealth decile. Y-axis is earnings decile. Shading represents different prescribed levels of saving with the darkest representing zero or negative prescribed saving, and ligher regions representing need for greater saving. Contour lines are at intervals of $5.0 \%$. Contour plot corresponds to figure 4 . 


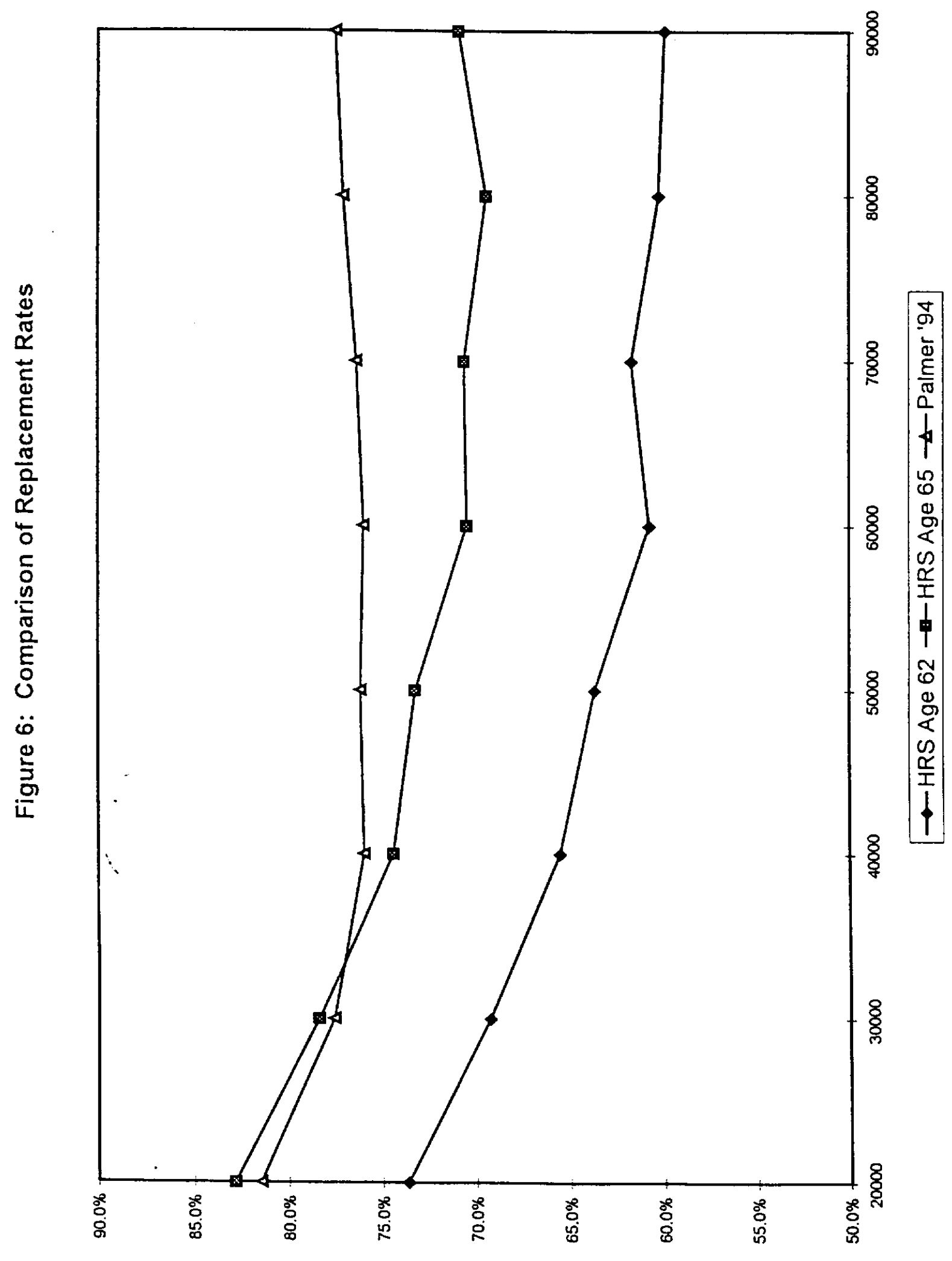

